\title{
КІЛЬКІСНЕ ВИЗНАЧЕННЯ МОНОСАХАРИДІВ РІДКОГО ЕКСТРАКТУ ЧЕБРЕЦЮ ПОВЗУЧОГО ТА ВИБІР КРИТЕРІЇВ ПРИЙНЯТНОСТІ
}

Вступ. В останні роки помітно зростає науковий інтерес до вивчення полісахаридів у лікарській рослинній сировині, що пов'язано з широким спектром їх фрармакологічної дії. У попередніх дослідженнях встановлено, що у витяжках із трави чебрецю повзучого (ЧП), одержаних за допомогою води і розчинів 3 низькою концентрацією спирту, наявні полісахариди, після гідролізу яких отримували моносахариди. Розробка муколітичного засобу на основі густого екстракту чебрецю повзучого й ефрірної олії чебрецю звичайного передбачала насамперед одержання рідкого екстракту ЧП, який отримували за підібраною технологією, що дозволила зберегти та відтворити аналізовані біологічно активні речовини трави ЧП. Тому з метою стандартизації рідкого екстракту ЧП важливо визначити не тільки їх якісний склад, а й кількісний вміст, що дозволить обрати відповідні показники якості та запропонувати критерії прийнятності.

Мета дослідження - провести кількісне визначення відновлювальних моносахаридів у рідкому екстракті чебрецю повзучого, вибрати відповідні критерії прийнятності.

Методи дослідження. Під час дослідження використано спектрофотометр “Сary-50”, рідкий екстракт чебрецю повзучого, ФСЗ: глюкози ("Fluka”), 1 \% розчин кислоти пікринової, 20 \% розчин натрію карбонату, 20 \%, 40 \% розчини натрію гідроксиду, кислоту хлористоводневу розведену Р.

Результати й обговорення. Кількісне визначення моносахаридів у рідкому екстракті ЧП проводили методом дифреренційної спектрофротометрії у видимій ділянці спектра за реакцією з пікриновою кислотою. Ïх вміст коливався у певних межах і визначався вмістом у вихідній сировині. Тому з метою здійснення стандартизації рідкого екстракту ЧП можна обрати кількісним критерієм якості вміст відновлювальних моносахаридів, а також запропонувати відповідні критерії прийнятності - не менше 0,09 \% у перерахунку на глюкозу.

Висновок. Проведено кількісне визначення відновлювальних моносахаридів у рідкому екстракті чебречю повзучого. В результаті визначено їх кількісний вміст та запропоновано критерії прийнятності.

КЛЮЧОВІ СЛОВА: чебрець повзучий; рідкий екстракт; спектрофротометрія; моносахариди; критерії прийнятності.

ВСТУП. Згідно з джерелами літератури, лікарські препарати на основі чебрецю повзучого (ЧП) широко використовують для лікування захворювань верхніх дихальних шляхів [1, 2].

Розробка нового муколітичного засобу на основі густого екстракту чебрецю повзучого й ефірної олії чебрецю звичайного передбачала підбір оптимального способу одержання рідкого екстракту ЧП, що дозволив отримати екстракт зі стабільним і відтворюваним вмістом аналізованих біологічно активних речовин сировини ЧП [3].

У попередніх дослідженнях встановлено, що трава ЧП багата на полісахариди [4]. Досвід есрективного застосування лікарських препара(C) H. О. Зарівна, 2021. тів на основі ЧП, одержаних за допомогою низької концентрації спирту або води, наштовхує на пошук цих біологічно активних речовин і в отриманому екстракті, що відповідатимуть саме за муколітичну активність [5]. Тому доречно визначити не тільки їх якісний склад, а й кількісний вміст у досліджуваному екстракті чП.

Мета дослідження - провести кількісне визначення відновлювальних моносахаридів у рідкому екстракті чебрецю повзучого, вибрати відповідні критерії прийнятності.

МЕТОДИ ДОСЛІДЖЕННЯ. Кількісне визначення відновлювальних моносахаридів у рідкому екстракті ЧП проводили методом дисреренційної спектросоотометрії за реакцією з пікрино- 
вою кислотою (відновлення пікринової кислоти до пікрамінової), використовуючи спектрофотометр "Cary-50" [6].

РЕЗУЛЬТАТИ Й ОБГОВОРЕННЯ. СПеКтрофотометричне визначення відновлювальних моносахаридів у рідкому екстракті ЧП проводили за допомогою чутливого і селективного методу аналізу - диференційної спектрофротометрії у видимій ділянці спектра. Оскільки стандартом для розрахунку кількісного вмісту відновлювальних моносахаридів у сировині ЧП було обрано глюкозу, при контролі якості досліджуваного екстракту необхідно розраховувати їх кількість у перерахунку на цю речовину [4].

Для кількісного визначення моносахаридів у рідкому екстракті чП було застосовано таку методику.

Вихідний розчин (а). 10,0 мл рідкого екстракту (точна наважка) поміщають у центрифужну пробірку місткістю 50 мл, додають 30,0 мл 96 \% спирту $P$, перемішують і нагрівають на водяній бані при температурі $30{ }^{\circ} \mathrm{C}$ протягом 5 хв. Витримують 1 год, вміст центрифугують, надосадову рідину відкидають, а осад переносять за допомогою 5,0 мл кислоти хлористоводневої розведеної $P$ та 5,0 мл води $P$ у конічну колбу місткістю 50 мл зі шліфом та нагрівають упродовж 1 год на киплячій водяній бані зі зворотним холодильником. Колбу зі вмістом охолоджують, поміщають у неї невеликий шматок паперу конго і додають по краплях 40 \% розчин натрію гідроксиду до почервоніння паперу, потім - по краплях кислоту хлористоводневу розведену до посиніння паперу, далі - по краплях $10 \%$ розчин натрію гідроксиду до почервоніння паперу. Отриманий розчин кількісно переносять за допомогою води Р у мірну колбу місткістю 25 мл, доводять об'єм розчину водою $Р$ до позначки, перемішують і фрільтрують, відкидаючи перші 5,0 мл фрільтрату (розчин A).

Випробовуваний розчин (а). 1,0 мл 1 \% розчину кислоти пікринової поміщають у плоскодонну колбу місткістю 25 мл, додають 3,0 мл 20 \% розчину натрію карбонату й 1,0 мл розчину А. Колбу зі вмістом витримують на киплячій водяній бані протягом 10 хв, потім охолоджують до кімнатної температури. Вміст колби кількісно переносять за допомогою води Р у мірну колбу місткістю 25 мл і доводять об'єм розчину водою $P$ до позначки.

Розчин стандартного зразка глюкози. 0,14 г (точна наважка) стандартного зразка глюкози ("Fluka"), висушеної при температурі від 100 до $105^{\circ} \mathrm{C}$ до постійної маси, поміщають у мірну колбу місткістю 100 мл, розчиняють у 50,0 мл води Р, доводять об'єм розчину водою $Р$ до позначки і перемішують. 10,0 мл одержаного розчину поміщають у мірну колбу місткістю 25 мл, доводять об'єм розчину водою $Р$ до позначки і перемішують.

Розчин порівняння. 1,0 мл 1 \% розчину кислоти пікринової, 3,0 мл 20 \% розчину натрію карбонату й 1,0 мл розчину стандартного зразка глюкози, оброблений аналогічно досліджуваному розчину, починаючи зі слів: "Колбу зі вмістом витримують...".

Компенсаційний розчин. 1,0 мл 1 \% розчину кислоти пікринової, 3,0 мл 20 \% розчину натрію карбонату й 1,0 мл води P, оброблений аналогічно досліджуваному розчину, починаючи зі слів: “Колбу зі вмістом витримують...”.

Оптичну густину випробовуваного розчину і розчину порівняння вимірюють при довжині хвилі 460 нм відносно компенсаційного розчину.

Вміст відновлювальних моносахаридів у рідкому екстракті (у відсотках) у перерахунку на глюкозу визначають за формулою:

$$
\mathrm{X}_{1}=\frac{\mathrm{A}_{\mathrm{x}} \cdot \mathrm{m}_{0}}{\mathrm{~A}_{0} \cdot 10 \cdot \mathrm{m}} \cdot 100
$$

де $A_{x}$ - оптична густина випробовуваного розчину;

$\mathrm{A}_{0}$ - оптична густина розчину порівняння;

$\mathrm{m}_{0}$ - маса наважки стандартного зразка глюкози, г;

m - маса екстракту, взятого для аналізу, г.

Результати кількісного визначення відновлювальних моносахаридів наведено в таблиці.

Кількісний вміст відновлювальних моносахаридів у досліджуваному екстракті коливався і визначався вмістом у вихідній сировині ЧП та відтворюваністю вибраної технології екстракту.

Керуючись результатами кількісного визначення відновлювальних моносахаридів, при стандартизації рідкого екстракту чебрецю повзучого можна запропонувати критерієм якості вміст відновлювальних моносахаридів не менше 0,09 \% у перерахунку на глюкозу.

Таблиця - Результати визначення вмісту відновлювальних моносахаридів у рідкому екстракті чебрецю повзучого ( $\mathrm{P}=0,95 ; \mathrm{n}=5)$

\begin{tabular}{||c|c|c|c||}
\hline \multicolumn{4}{|c|}{$\begin{array}{c}\text { Вміст відновлювальних моносахаридів } \\
\text { у перерахунку на глюкозу, \% }\end{array}$} \\
\hline № 1 & № 2 & № 3 & № 4 \\
\hline $0,113 \pm 0,020$ & $0,121 \pm 0,020$ & $0,101 \pm 0,003$ & $0,121 \pm 0,002$ \\
\hline
\end{tabular}


ВИСНОВКИ. 1. Проведено кількісне визначення відновлювальних моносахаридів у рідкому екстракті чебрецю повзучого.
2. Визначено кількісний параметр якості вміст відновлювальних моносахаридів та обрано відповідний критерій прийнятності-не менше 0,09 \% у перерахунку на глюкозу.

\section{СПИСОК ЛІТЕРАТУРИ}

1. Лікарські рослини і фрітотерапія (фрітотерапевтична рецептура) : навч. посіб. / Л. В. Бензель, Р. Є. Дармограй, П. В. Олійник, І. Л. Бензель. - К. : Медицина, 2010. - 400 с.

2. Соколов С. Я. Фитотерапия и фритофрармакология : руководство для врачей / С. Я. Соколов. - М. : МИА, 2000. - 976 C.

3. Пат. 73543 Україна, МПК ${ }^{51}$ С 11 В 1/10, А 61 К 9/08, А 61 K 35/00. Спосіб отримання рідкого екстракту чебрецю повзучого / Н. О. Зарівна, Л.В.Вронська, Т. А. Грошовий ; заявник і патентовласник Терноп.

\section{REFERENCES}

1. Benzel, L.V., Darmohrai, R.Ye., Oliinyk, P.V., \& Benzel, I.L. (2010). Likarski roslyny i fitoterapiia (fitoterapevtychna retseptura: navch. posib.) [Medicinal plants and phytotherapy (phytotherapeutic formulation)]. Kyiv: Medytsyna [in Ukrainian].

2. Sokolov, S. Ya. (2000). Fitoterapiya i fitofarmakologiya: rukovodstvo dlya vrachey [Phytotherapy and phytopharmacology: a guide for doctors]. Moscow: MIA [in Russian].

3. Zarivna, N.O., Vronska, L.V., \& Hroshovyi, T.A. (2012). Pat. Ukrainy, Sposib otrymannia ridkoho ekstraktu chebretsiu povzuchoho [The method of obtaining liquid creeping thyme extract]. № 73543 MPK51 S 11 V 1/10, A 61 K 9/08, A 61 K 35/00; Biul. №18 [in Ukrainian].

держ. мед. ун-т імені І. Я. Горбачевського. - Заявл. 26.03.12 ; опубл. 25.09.12, Бюл. № 18.

4. Зарівна Н. О. Вивчення водорозчинних полісахаридів чебрецю повзучого / Н. О. Зарівна, Л. В. Вронська, М. Б. Чубка // Фармац. часоп. - 2012. - № 2. C. $56-61$.

5. Компендиум 2007 - лекарственные препараты / под ред. В. Н. Коваленко, А. П. Викторова. - К. : МОРИОН, 2007. - 2270 с.

6. Практикум по фрармакогнозии / под ред. В. Н. Ковалева. - Х. : Золотые страницы, 2003. - С. 40-45.
4. Zarivna, N.O., Vronska, L.V., \& Chubka, M.B. (2012). Vyvchennia vodorozchynnykh polisakharydiv chebretsiu povzuchoho [Study of water-soluble polysaccharides of creeping thyme]. Farmatsevtychnyi chasopys - Pharmaceutical Review, 2, 56-61 [in Ukrainian].

5. Kovalenko, V.N., \& Vyktorova, A.P. (2007). Kompendium - lekarstvennye preparaty [Compendium medicines]. Kyiv: MORION [in Ukrainian].

6. Kovalev, V.N. (2003). Praktikum po farmakognozii [Workshop on harmacognosy]. Kharkiv: Zolotye stranitsy [in Russian].

Н. О. Заривна

ТЕРНОПОЛЬСКИЙ НАЦИОНАЛЬНЫЙ МЕДИЦИНСКИЙ УНИВЕРСИТЕТ ИМЕНИ И. Я. ГОРБАЧЕВСКОГО МОЗ УКРАИНЫ

\section{КОЛИЧЕСТВЕННОЕ ОПРЕДЕЛЕНИЕ МОНОСАХАРИДОВ ЖИДКОГО ЭКСТРАКТА ТИМЬЯНА ПОЛЗУЧЕГО И ВЫБОР КРИТЕРИЕВ ПРИЕМЛЕМОСТИ}

\section{Резюме}

Вступление. В последние годы заметно возрастает научный интерес к изучению полисахаридов в лекарственном растительном сырье, что связано с широким спектром их фрармакологического действия. В предыдущих исследованиях установлено, что в выдержках из травы тимьяна ползучего (ТП), полученных с помощью воды и растворов с низкой концентрацией спирта, содержатся полисахариды, после гидролиза которых получали моносахариды. Разработка муколитического средства на основе густого экстракта тимьяна ползучего и эфрирного масла тимьяна обыкновенного предусматривала прежде все- 
го получение жидкого экстракта ТП, который получали по подобранной технологии, которая позволила сохранить и воспроизвести анализируемые биологически активные вещества травы ТП. Поэтому с целью стандартизации жидкого экстракта ТП важно определить не только их качественный состав, но и количественное содержание, что позволит выбрать соответствующие показатели качества и предложить критерии приемлемости.

Цель исследования - провести количественное определение восстановительных моносахаридов в жидком экстракте тимьяна ползучего, выбрать соответствующие критерии приемлемости.

Методы исследования. Во время исследования использовано спектрофотометр “Сагу-50”, жидкий экстракт тимьяна ползучего, ФСО: глюкозы (“Fluka”), 1 \% раствор кислоты пикриновой, 20 \% раствор натрия карбоната, 20 \%, 40 \% растворы натрия гидроксида, кислоту соляную разведенную $P$.

Результаты и обсуждение. Количественное определение моносахаридов в жидком экстракте ТП проводили методом диффреренциальной спектрофотометрии в видимой области спектра по реакции с пикриновой кислотой. Их содержание колебалось в определенных пределах и определялось содержанием в исходном сырье. Поэтому с челью осуществления стандартизации жидкого экстракта ЧП можно выбрать количественным критерием качества содержание восстановительных моносахаридов, а также предложить соответствующие критерии приемлемости - не менее 0,09 \% в пересчете на глюкозу.

Вывод. Проведено количественное определение восстановительных моносахаридов в жидком экстракте тимьяна ползучего. В результате определено их количественное содержание и предложено критерии приемлемости.

КЛЮЧЕВЫЕ СЛОВА: тимьян ползучий; жидкий экстракт; спектрофотометрия; моносахариды; критерии приемлемости.

N. O. Zarivna

I. HORBACHEVSKY TERNOPIL NATIONAL MEDICAL UNIVERSITY

\title{
QUANTITATIVE DETERMINATION OF MONOSACCHARIDES OF LIQUID THYME CREEPING EXTRACT AND SELECTION OF ACCEPTANCE CRITERION
}

\begin{abstract}
Summary
Introduction. In recent years, there has been a growing scientific interest in the study of polysaccharides in medicinal plant raw materials, which is due to their wide range of pharmacological action. Previous studies have shown that polysaccharides are present in extracts of creeping thyme (CT) obtained with water and solutions with low concentrations of alcohol, after hydrolysis of which monosaccharides have been obtained. Because, the development of a mucolytic agent based on a thick extract of emergency and essential oil of thyme involved, first of all, obtaining a liquid extract of emergency, which was obtained by the selected technology, which allowed to preserve and reproduce the analyzed BAS herbs. Therefore, in order to standardize the liquid extract of the state of emergency, it is important to determine not only their qualitative composition, but also the quantitative content, which will allow to choose the appropriate quality indicators and offer acceptability criteria.
\end{abstract}

The aim of the study - quantitative determination of monosaccharides in liquid extract of CT, selection of appropriate acceptance criteria.

Research Methods. Spectrophotometer "Cary-50", liquid extract of creeping thyme, FSE: glucose (Fluka), $1 \%$ solution of picric acid, $20 \%$ solution of sodium carbonate, $20 \%, 40 \%$ solution of sodium hydroxide, dilute hydrochloric acid $R$.

Results and Discussion. Quantitative determination of monosaccharides in the liquid extract of CT was performed by differential spectrophotometry in the visible part of the spectrum by reaction with picric acid. Their content varies within certain limits and is determined by the content in the raw material. Therefore, in order to standardize the liquid extract of CT, you can choose a quantitative quality criterion - the content of reducing monosaccharides, as well as to propose appropriate acceptance criteria - not less than $0.09 \%$ in terms of glucose.

Conclusion. Quantitative determination of reducing monosaccharides in liquid extract of CT is carried out. As a result, their quantitative content was determined and eligibility criteria were proposed. criteria.

KEY WORDS: creeping thyme; liquid extract; spectrophotometry; monosaccharides; acceptability

Отримано 23.02.21

Адреса для листування: Н. О. Зарівна, Тернопільський національний медичний університет імені І. Я. Горбачевського мОз України, майдан Волі, 1, Тернопіль, 46001, Україна, e-mail: zarivna@tdmu.edu.ua. 